\title{
Analysis on the Impact of Citizen's Miss Behavior on Democratic Praxis Based on the Pancasila Values
}

\author{
Abdul Azis Wahab, Dede Iswandi \\ Universitas Pendidikan Indonesia \\ Bandung, Indonesia \\ abdulaziswahab1@gmail.com
}

\begin{abstract}
Constitutionally ideals of Democracy for Indonesia is a concept of democracy based on the fourth principle of Pancasila. This paper is intended to explore ideas or ideas from people led by the spirit that comes from and within the people's representative institutions. The foundation of democracy, which is the essence of authority, the essence of the responsibilities, duties and right of citizens and public responsibility must integrate holistically the essence of religiousity, humanity, nationalism, democracy and social justice pronounce right by the ideal of Pancasila. The method used in this study is literacy study by examining various sources of literature. Finding from this study examines the implementation of democracy in Indonesia in instructing and actualizing values and morality that harmonize responsibility, and a sense of law for all people. This finding is also a form of responsibility with the full responsibility of all members.
\end{abstract}

Keywords-duties and rights of citizens; foundation of democrarcy; public resposubility; the core of justice; the essence of authority; the ideals of pancasila

\section{INTRODUCTION}

In the face of the rapidly changing environment of being a good citizen (Good citizen) is not enough but must also be a smart citizen (Smart citizen) and of course must be democratic as the goal of Civic Education Indonesia (Civics) today. This means that the Indonesian Civil Code which according to the Curriculum 2013 becomes Pancasila and Citizenship Education (PPKn) must produce good citizens smart and democratic.

Tichenor, Donohue, and Olien proposed the knowledge gap hypothesis as follows: As the infusion of mass media information into a social system increases, segments of the population with higher socioeconomic status tend to acquire this information at a faster rate than the lower status segments, so that the gap in knowledge between these segments tends to increase rather than decrease (pp. 159-160) [1].

To achieve this is done through Civic Education (Civic Education) whose legal basis is contained in the Law of the Republic of Indonesia No. 20 of 2003 on National Education System (UUSPN). The legal basis as stated in Article 37 UUSPN No.20 of 2003 it reads:

(1) The curriculum of primary and secondary education shall contain:

- religious education;
- civic education;

- language; etc.

The above quotation also explains that Civics should be included in the curriculum of primary and secondary education. If listed in the curriculum it also means to be taught through the school curriculum for both primary and secondary education, as stated in Article 37 of the UUSPN.

Issues such as social justice are perceived to be inappropriate to be taught to young children because of its complexity $[2,3]$. Therefore, it is necessary to adjust the social justice material curriculum in schools that are taught to young people. In its development to date the Civics in Indonesia has undergone various name changes through changes in the school curriculum

In its development to date the Civics in Indonesia has undergone various name changes through changes in the school curriculum. It is said that because the values of Pancasila democracy especially the fourth principle of Pancasila has not been well implemented. The situation has been exacerbated by reforms that are not followed by the steps or actions that lead to reforms to mental reforms in line with the demands for the transition of political power from the New Order regime

His main background is in accordance with that described William Liddle in his paper titled "Indonesia's Unexpected Failure of Leadership" in The Politics of Post-Suharto Indonesia p:16-17 by saying that: How can we explain Suharto's rapid political demise , after so many years of nearabsolute power? Age Suharto turned 77 in June 1998 was undoubtedly a factor, as was the department of the economic crisis, the most serious that Indonesia has experience since the beginning of New Order government established by Suharto 1965-66 [4].

More important, however was a series of presidential policy missteps that worsened and prolonged the crisis. "All of that is as a trigger" overflow "in various areas of life, social politics and economics. Further impacts include the occurrence of citizen's misbehavior or miss-behavior that is inconsistent with the wisdom of the Pancasila noble and wise. 


\section{LITERATURE REVIEW}

Indonesian democracy as a concept as mentioned above is based on the values of Pancasila in particular the value of the value contained in the fourth value of Pancasila. In the fourth precepts contains an important point of Indonesian democracy, namely Pancasila democracy includes the dimensions:

\section{A. Democracy}

In the concept of Indonesian democracy is Pancasila Democracy the people are sovereign. In the 1945 Constitution Chapter I form and sentential article 1 reads:

- The State of Indonesia is the Unitary State, which is a Republic.

- Sovereignty is in the hands of the people, and is carried out entirely by the People's Consultative Assembly;

The article explains that the state of Indonesia is a unitary State in the form of a Republic, not a state of power and hence the sovereign is fully undertaken by the People's Consultative Assembly. It is manifested from the existence of representatives that are turned on and developed in the work process of the legislative body or the House of Representatives, the Regional House of Representatives and the Regional Representative Council. The fourth dimension of Pancasila's precepts, if described in more detail, explains that the Indonesian state is democratically depicted with the sovereignty of the people.

Why that is because of moral action as proposed by Lickona p: 53 must have competence, there is will / desire and habit [5]. It indicates that democratic values must be grown from an early age. Gross and Zelleny in Azis Wahab and Sapriya for example explains that: The community needs children and youth who have a wide knowledge of the ideal democracy that is reflected in the relationship with others who are also skilled in practicing it as a good citizen whose characteristics has been put forward by a competent institution based on the results of his studies are:

Detroit Citizenship Education Study characterized good citizens by defining him in terms of five essential qualities as one who: (1) cherishes democratic values and bases his action on them; (2) recognizes the social problems of the time and has the will and the ability to work toward their solutions; (3) is aware and takes responsibility for meeting basic human needs ; (4) practices democratic human relations in the family, school, and community; and (5) possesses and uses, knowledge, skills, and abilities necessary in a democratic society [6].

PPKn aims to produce a democratic society that is supported by individual citizens. The results of Hindman and McCright and Dunlap indicate that a more detailed look at the relation between education and ideology may increase our under- standing of any potential tension between them [7, 8]. In accordance with the above opinion Education and ideology are two things that cannot be separated because with Education can improve understanding and implement well the concepts and principles of democracy as one of the goals of Civic Education and also carried out in PPKn in school.
Ideology Pancasila as also put forward by Soerjanto Puspowardoyo in Oetoyo, Oesman and Alfian that: "... ideology is a clear choice and bring a commitment to make it happen, followed by Sastrapratedja who argued that ideology contains an orientation to action [9]. Thomas Lickona in his book Building Character such as discussing about "moral values" in relation to values and character and cannot be separated from teaching respect and responsibility. Lickona explains that: Moral values such as responsibility and fairness of carry obligation. We feel obligated to keep a promise, pays our bill, care for our children, and be fair in our dealings with others [5].

Moral values tell us what we ought to do. (1991) p: 38. However, they should be based on the teacher's role as caregiver, model and mentor, p: 71 and based on good character components including morale knowing, moral feeling and moral action, which are interconnected with each other, $\mathrm{p}$ : 53. The above view can help to overcome the occurrence of deviant behavior or democracy with excess freedom as the impact of reforms that are not well directed.

\section{METHOD}

The method uses various literatures obtained from various reference sources such as books, journals, and other literary sources related to democracy based on the values of Pancasila.

\section{RESULT AND DiSCUSSION}

\section{A. Basic Basis and Democracy Life Indonesia}

Indonesian democracy is a Pancasila democracy based on the values contained in the principles of Pancasila. The relation between the values of Pancasila is very strong and solid where the four other precepts are as a whole based on the first precepts of the Divinity of the One Supreme God.

For me the moral ideals of the noble Indonesian people are the Basic State of Pancasila. However the principle of Pancasila which is directly related to Pancasila democracy which is the focus of our discussion in relation to its implementation in the era of freedom as a result of reform is the fourth principle of Pancasila, namely: "People's sovereignty led by the wisdom of wisdom in representatives deliberations." the values expressed in the four principles of Pancasila are the foundation and core of Pancasila democracy which also includes authority, justice, obligations and rights and responsibilities of citizens.

The Republic of Indonesia as one of the democratic countries always strives for the concept and basic principles of democracy to be implemented well in the framework of society, nation and state. "Influenced by the political and social urgency of their environment" [10]. Therefore the ideals together can always be carried out properly in the context of society, nation and state. This is the idea of popular sovereignty which is led by the spirit obtained through the spirit of "Wisdom in Consultative Representative Policy." In order for Pancasila democracy practices to be understood and carried out properly in the life of the nation and state society. 
There is a general understanding that ideology is central to the strength, viability, and solidarity of a party. It also distinguishes parties from each other in the political system $[11,12]$. The view above, a modern state with a written constitution, the people are sovereign. As a modern state with a written constitution, it is appropriate if the representative government becomes one of its characteristics depicted through political parties, social organizations / mass organizations that are legally protected under the Ordinance of the Society and the Political Party Act in carrying out its function as a container and channeling the aspirations of a democratic society, through a representative form or a representative government as a fundamental requirement of a democratic government.

In implementing Pancasila democracy practice, as mentioned above, especially in decision making must always be led by the wisdom of wisdom (wisdom 1 wisdom, 2 supernatural power). Taking or making decisions, especially those concerning the livelihood of people many must be done well that is by ikhlas, honest and responsible Java and carefully based on the spirit of togetherness.

There are many factors that influence the decision-making process because it is the process "which must be led by Wisdom" so that good and correct decisions and usefulness can be produced. Wisdom can also mean wisdom or wisdom. By matching the word "wisdom" to "wisdom" which also means wisdom it is appropriate that it emphasizes the importance of the principle in the dimension led by the wisdom of wisdom in every decision making, especially decisions concerning the interests of the people.

\section{B. Purpose and Improvement of Democracy of Pancasila}

The realization and practice of Pancasila democracy is the implementation of the 1945 Constitution in the implementation of the government of the Republic of Indonesia. This is in line with the views expressed by the leadership of the People's Consultative Assembly of the Republic of Indonesia period 2014 -2019 in his speech. It is argued that: "The Constitution of the Republic of Indonesia Year 1945 is the constitution of the state of Indonesia which was first established by the founders of the state on August 18, 1945. As a basic law, the 1945 Constitution of the State of the Republic of Indonesia is not only a legal document but also contains other aspects such as the view of life, ideals and philosophy which are the noble values of the nation and become the basis in the administration of the state. "Law State Gazette of The Republic of Indonesia Year 1945, MPR RI Secretariat General 2017 XV.

Based on the above view is explained that the 1945 Constitution is not only a legal document but also has other meanings and also contains other important aspects such as the view of life, ideals and philosophy which is the noble values of the nation and a reference in the implementation of the state. View of life, ideals and philosophy which is the noble value of the nation. Above I have pointed out that for me the noble value of the nation is Pancasila as well as a view of life, ideals and philosophy of life of the nation. "Although ideally the conceptual an open ideology such as Pancasila is known and believed by society or nation to have excellent qualities it has not guaranteed its proper manifestation, realization and appropriateness or as it is intended by the ideology in their societal, national and state life, with various fields.

The impact of forced perceptions to perpetuate power and win their interests for a long period of time has been demonstrated by the governments of the Old Order and the New Order (the Soekarno and Soeharto Regimes). Based on that he suggests three levels or stages of awareness of our society and nation against Pancasila as ideology, namely: (1) Pancasila as the ideology of unity, (2) Pancasila as development ideology, and (3) Pancasila as open ideology. Pancasila as the ideology of unity serves to unite our society that multicultural "every moment of the life of a society, culture is the result, with more or less awakened consciousness, of economic and political activities, the more or less dynamic expression of the type of relations prevailing within that society" [13]. Pancasila as the nation's ideology is able to unite cultural differences in Indonesia that serve to unite a diverse society into a nation that has personality and self-confidence, while as an ideology of development it provides legitimacy of power to carry out national development.

As an open ideology Pancasila needs to outline its basic values through critical interpretation and reinterpretation making it even more operational. It becomes a dynamic ideology. "The three levels of Pancasila ideology and its explanation have basically given the right direction on how Praxis Pancasila Demax should be run in various levels and areas of community life that are often abbreviated to society, nation and state.

\section{Reform and Democracy with Behavioral Conduct}

Factors causing the behavior of citizens who exodus Citizen's miss-behavior. In the reform process everyone felt that they had rediscovered the freedoms that during the New Order government were perceived as impossible to recall because too many rules restrict citizens' freedom to express themselves, to convey their thoughts and opinions even to students who always occupy the forefront of each movements to correct policies that conflict with the values of Pancasila Democracy.

The values that can guide and control freedom are legal values, laws and regulations based on the noble values of Pancasila and in accordance with the constitution of the Indonesian state known as Constitutional Democracy.

Behavior spreads hatred through social media or commits extraordinary crimes of corruption, collusion and nepotism. Other behaviors are increasingly lax Bonds of kinship, respect for the rules and laws, state apparatus and state officials declining, examples and behavior of leaders who are far from exemplary as a nation that upholds human dignity and prestige. Behavior of respect and respect for others, a sense of responsibility and shame such as: respect, responsible and shame culture, which decreases causing deviant behavior or often termed by excessive democratic behavior.

Why is that because the implementation of democracybased life of Pancasila values, especially the fourth precepts of Pancasila has not been well implemented, or well-practiced in everyday life in the community, in running the state 
government. The Reform Era should prioritize freedom as one of the main fundamentals besides the implementation or praxis of the value of democracy based on the values of Pancasila.

\section{Establishing a Good and Smart Citizen and also Pancasilais}

Freedom as an essential part of political reform and is an important thing in Indonesia's democratic state should be understood and implemented properly and proportionately. That is why citizen's miss-bauma is not avoided let alone be left but it must be addressed through the program of PPKn Civic Education which is designed and done well through the school curriculum and balanced by building public awareness about the importance of practicing Pancasila values with full awareness, responsibility and mutual trust in daily life, in government, nation and state through Citizenship education.

Implementation of freedom alone without associated with other democratic fundamentals such as the essence of authority, the core of justice, duties and right of citizens and public responsibility in implementing that freedom does not give a positive impact of life that is democratic prosperous society. Authority possessed by a person or group of people should be used as well as possible in democratic life.

On the other hand, the nuances of freedom alone without being fully integrated with other basic democratic values such as religiousity, humanity, nationalism, democracy and social justice will not give meaning useful to the implementation of democracy and even contrary counter-productive with the values of democracy.

\section{CONCLUSION}

In the face of the rapidly changing environment of being a good citizen (Good citizen) is not enough but must also be a smart citizen (Smart citizen) and of course must be democratic as the goal of Civic Education Indonesia (Civics) today. This means that the Indonesian Civil Code which according to the Curriculum 2013 becomes Pancasila and Citizenship Education (PPKn) must produce good citizens smart and democratic. Analyzing the behavior of deviant citizens in implementing Pancasila Democracy is not an easy thing but it does not mean it cannot be done.

Culture is simultaneously the fruit of a people's history and a determinant of history, by the positive or negative influence it exerts on the evolution of relations between man and his environment and among men or human groups within a society, as well as between different societies [13]. In accordance with the above opinion what needs to be understood from that situation is what lies behind it and understands its characteristics so that the most sensible solution in understanding the history of the long journey of Banga Indonesia will help us understand it more carefully and get the right opportunities to overcome it instead of avoiding it.

With repressive or almost absolute power which is then followed by reforms that are not accompanied in the right direction is one of the causes of the overt freedom of democracy, or citizen's miss-behave. The causes and their impacts in democratic practice have been mentioned above including how to overcome them by relying on PPKn or Civic Education for the school level and Citizenship Education for the community in general.

\section{REFERENCES}

[1] P.J. Tichenor, G.A. Donohue, and C.N. Olien, "Mass media flow and differential growth in knowledge," Public opinion quarterly, vol. 34, no. 2, pp. 159-170, 1970.

[2] E. Burman, Developments: Child, image, nation. Routledge, 2008.

[3] V. Walkerdine, Daddy's girl: Young girls and popular culture. Harvard University Press, 1998.

[4] A. Schwarsz and J. Paris, The Politic of Post-Suharto Indonesia. New York: Councils on Foreign Relations Press, 1999.

[5] T. Lickona, Educating For Character : How Our Schools Can Teach Respect and Responsibility. New York: Bantam Books, 1991.

[6] E. Richard, Gross and L.D. Zeleny, Educating Citizens for Democracy : Curriculum and Instruction, In Secondary Social Studies. New York: Oxford University Press, 1958.

[7] D.B. Hindman, "Mass media flow and differential distribution of politically disputed beliefs: The belief gap hypothesis," Journalism \& Mass Communication Quarterly, vol. 86, no. 4, pp. 790-808, 2009.

[8] A.M. McCright and R.E. Dunlap, "Cool dudes: The denial of climate change among conservative white males in the United States," Global environmental change, vol. 21, no. 4, pp. 1163-1172, 2011.

[9] O. Oesman dan Alfian, (Penyunting) Pancasila Sebagai Ideologi: Dalam Berbagai Bidang Kehidupan Bermasyarakat, Berbangsa Dan Bernegara. Bp 7 pusat h:8, 1991.

[10] M.M. Makumba, An introduction to African philosophy: Past and present. Paulines Publications Africa, 2007.

[11] F. Vassallo and C. Wilcox, Party as a Carrier of Ideas. Handbook of party politics, pp. 413-421, 2006.

[12] A. Volkens and H.D. Klingemann, Parties, ideologies, and issues. Stability and change in Fifteen European Party Systems 1945-1998. Political parties in the new Europe: Political and analytical challenges, pp. 143-167, 2002.

[13] M. Wolfers, Poems from Angola (Vol. 215). Heinemann Educational Books, 1979. 